\title{
Change of International Aviation Order: From International Regime Perspective*
}

\author{
Lee, Jong-Sik \\ (H ankuk Aviation University)
}

\section{$\langle$ CONTENTS〉}

I. Introduction

II. Change Of International Aviation, and Politics

1. Formation, change, and development of international aviation regimes

2. Change of the international politics as regime theories

III. Power Structure

IV. Economic and Technological Importance

1. Economic Growth

2. Technological Development
V. Issue Structure

1. Ownership of Air Carriers

2. Market Order

3. Relationship with WTO

VI. International Organizations

1. The 3rd Organizations

2. Aviation NGOs

3. Networks with Customer Relationship

VII. Models and Restyles

1. Models

2. Restyles

VIII. Conclusion

- Keyword: international aviation regime, power structure, economic growth and technological development, issue structure, international organization, models and restyles, state-centered, airlinecentered, customer-centered

\section{【ABSTRACT】}

This article aims to analyze elements (power structure, economic growth and technological development, issue structure, and international organizations) of international aviation regime change by time scopes, and to rebuild theoretical and analytical framework through modeling international aviation regimes of each time. The models of change in international aviation regimes for each time scope may be summarized into three models; state-centered on the realism theory of hegemonic stability, airline-centered on the neo-liberalism, and customer-

*The author wishes to thank three anonymous referees for their helpful comments. 
centered on the social constructivism. The developing international aviation regimes should be sought for the customers in the global society.

This article provides students with theoretical framework and policy- or decision-makers with useful analytical methods in international aviation regimes, which promote and facilitate people's movements throughout the globe. With the thorough understanding of the history of international regime change, and through efforts of various sectors to follow and keep up with such changes, the welfare and peace for the worldwide air transportation can finally be achieved.

\section{I . Introduction}

Today's international aviation order, such as international aviation organizations, bilateral and multilateral agreements, has been developed from the Convention on International Civil Aviation of Chicago Conference in 1944, which aimed to establish international aviation orders after the World War $\mathbb{I}$. The US aviation deregulation policy in the late 1970s, 'open skies' agreements and airlines alliance in 1990s are constituted on the basis for the development and improvement of such orders that started in the Chicago Conference.

However, the uncertainties of these international aviation orders are currently being amplified due to various factors from outside the industry, such as 9.11 terrorist attacks, SARS, the war in Iraq, and soaring oil prices. Facing such uncertainties, aviation policy-makers are seeking for their ways to meet the challenges by reinforcing the frameworks and institutions of international aviation orders ${ }^{1)}$. Unlike the past, in the international field so diversified as today, it requires mutual collaboration in many fields in order to get rid of such uncertainties. It is considered that many studies on international orders are carried out in various fields of international relations in such regard (Keohane and Nye 1989: 1-22). The representing actors of international aviation field are the state, the air transport industry - or air carriers - and the user of air transport services (Zylicz 1991: 9). This study aims to investigate on how these three actors came to cope with the change of geopolitical international aviation order, which is

1) The policy-makers of each country facing such exogenous uncertainty examined aviation principles and guidelines to present correct information leading to a specific conclusion, and revised their feasibility (Downs 1957: 83-84). 
based on the pluralism and neo-liberalism since the late 1970s, and on the international cooperation among the major actors in world politics since the 1990s (Grieco 1993: 328335). The aims of this study can be specified in brief as follows: 1) to consistently explain the stages of international aviation transition, 2) to analyze and model the characteristics in each stage of the transition, and 3) to compare the differences of transition stages, and restyle a theoretical framework for new international aviation orders.

The main sources used in this study are conventions and agreements such as the Chicago Convention of 1944, the bilateral air services agreements, and agreed minutes such as 'ICAO Worldwide Air Transport Conference ${ }^{2)}$ on Challenges and Opportunities of Liberalization' held in Montreal, Canada, during March 24-28, 2003.

The time scope of this study is from the Paris Convention of 1919, when the first basic framework of international aviation orders was established, to the year 2005. This time period is explained in three stages based on the transformation of international aviation orders: the $1^{\text {st }}$ stage from the Paris Convention of 1919 to the US deregulation of domestic market in 1978; the $2^{\text {nd }}$ stage from 1978 to the 'open skies' agreement between the US and the Netherlands in 1992; the $3^{\text {rd }}$ stage from 1992 to the present when there exist various forms of international aviation systems.

This study would like to analyze even the fields left untouched by some scholars including Christer Joensson, especially focusing on the transformation of international regimes since globalization after the 1990s (Joensson 1981: 273-302). According to Arthur Stein, Robert Keohane and Joseph Nye, the factors of regime change in international politics are mainly thought as follows: power, economic growth, technologies, and knowledge (Stein 1993: 41-47: Keohane and Nye 1989). It is also thought such factors in the international aviation are very important as external variables. The ones (power structure and economic growth) are more important than the other (technologies and knowledge) in the hierarchical orders. This article explores and analyzes four kinds of the independent variables, especially, power structure and economic growth as the external variables, and issue structure and international organizations as the internal variables with the below assumption for change of international regimes in the international aviation fields (Keohane and Nye 1989).

The developing direction for international regimes is from the state-centered

2) ICAO Annual Meeting of 2003 was held with the agenda on 'Challenges and Opportunities of Liberalization' in Montreal, Canada, and resulted in Agreed Minutes.

3) This bilateral agreement between US and the Netherlands was the first 'open skies' one without any restrictions. 
governance to the people-centered governance which shared values and principles are able to give 'a human face' to the global market (Kofi Annan 1999). This study will try to contribute to the universalism of the globalism, that is, the spread of various objects and experiences to people at all corners of the world. In this regard, if the international aviation order is more globalized and de-regularized, we can assume that it will be cooperative for the civilian user as follows;

The more the international aviation stages develop to the recent, and the international aviation order is globalized, the more it will be oriented toward the customer-centered services.

Through analyzing the elements of international aviation regime change, this article will suggest modeling and restyling of characteristics for each stage of international aviation development. The following chapters will briefly review the formation, change, and development of international aviation regimes, and changes of international politics concerned with international aviation regimes (II), analyze important four independent variables for the regime change $(\mathbb{I I}-\mathrm{VI})$, and combine the time scope and independent variables, and remodel and restyle the change of international aviation regimes (VII).

\section{Change of International Aviation, and Politics}

\section{Formation, change, and development of international aviation regimes}

The international aviation regimes were established in the Chicago Conference in 1944. The main agendas of the Conference were three items: the $1^{\text {st }}$ is to set out the freedoms of the air ${ }^{4}$, the $2^{\text {nd }}$ is to build-up the Convention on International Civil Aviation, and the $3^{\text {rd }}$ is to establish the International Civil Aviation Organization (ICAO). These agendas are the important international aviation orders.

Since the Chicago Conference failed to produce an agreement regarding the exchange of commercial rights, representatives from Great Britain and the United States met again in Bermuda in 1946 to exchange operating rights between the two countries. The Bermuda Agreement resulted in the 'five freedoms' of the air. The first two freedoms were essentially those provisions agreed to at Chicago Conference specifically, the right

4) See: Rigas Doganis, 2001, The Airline Business in the 21st Century (London and New York: Routledge), p.227. 
to fly across another country's territory (1st freedom) and the rights to land for noncommercial, emergency purposes ( $2^{\text {nd }}$ freedom). The remaining freedoms were the rights to disembark in a foreign country passengers and cargo that had originated in the carrier's home country (3rd freedom), pick up from a foreign country passengers and cargo destined for the carrier's home country ( $4^{\text {th }}$ freedom), and transport passengers and cargo from one foreign country to another ( $5^{\text {th }}$ freedom). The principles, norms, rules, and decision-making procedures on the specific international air transport between two countries were conditioned and regulated in the bilateral agreements between the concerned countries, for example, such as Bermuda I and II between British Government and US Government ${ }^{5)}$.

The trends of neo-liberalism in the international politics were proliferated into the international aviation policy since the late 1970s. The Airline Deregulation Act of 1978 was facilitated by two occurrences. First, most major US airlines eventually came to support deregulation. Second, during 1978 the industry posted substantial profits and the public had access to a wide variety of discount fares. Politicians thus faced little risk of an outcry from either the industry or the public. Concerns about loss of service to small communities were relieved by providing a ten-year essential air service program (Taneja 1989: 28). These actions were extended to the International Airline Competition Act of 1980. Deregulation of the airline industry in the United State and the structural changes following it have also had a significant impact on the airline industry in other parts of the world. A trend toward liberalization is clearly evident in Canada, Western Europe, Australia, and Japan (Taneja 1989: 31).

In the 1990s, international aviation regimes are 'open skies agreements' through the transnational cooperation among states, especially, European Unions. In September 1992 the Dutch and United States' governments signed what was effectively the first 'open skies' agreement and inaugurated a new phase of international deregulation. In brief the key factors of this bilateral are as follows:

1) open route access

2) unlimited $5^{\text {th }}$ freedom rights

3) open access for charters

4) multiple designation of airlines

5) no frequency or capacity control

6) break of gauge permitted

7) no tariff controls

5) Ibid, p.21. 
8) airlines free to code share or make other commercial agreements

These actions of US government make airline service more free for users (Doganis, 2001: 32). Through the above courses, aviation regimes have been changed from statecentered regulation to user-centered deregulation after 1944 Chicago Conference on to the present.

\section{Change of the international politics as regime theories}

In case the previous time scopes are related with the international politics after the World War $\mathbb{I}$, the major theories for formation and emergence of international regimes ${ }^{6}$ referred in this article are the realistic theory of hegemonic power, in the 1970s the neo-liberalism, and in the 1990s the social constructivism based on shared understanding of inter-subjective knowledge for driving international cooperation (Wendt 1992: 391-425; Hascenclever, Mayer, and Rittberger 1997: 1-2).

\section{(1) Realism}

The Realistic theory of hegemonic stability maintains that the feasibility of international cooperation is dependent on the balance of state powers. That is, interstate cooperation and formation of international regimes are only possible under hegemonic structure in which one state owns the absolute power. The international regimes in certain issue-areas are formed by the power of such hegemony and for their own benefits (Gilpin 2001: 92-93).

According to this theory, a hegemonic state provides public goods for increasing their own national benefits, and the international regimes are created by the state power as one of such public goods (Krasner 1983: 13-16). Therefore, the aims and directions of international regimes created by this way are decided at the preference of the hegemonic state. Under such hegemonic structures, international regimes are formed in certain issue-areas, and the principles of the rules are well adhered to, the theory insists.

The maintenance of international regimes based on the hegemonic power depends on the power change of the hegemonic state. With the power deteriorating, its influences also weaken (Keohane 1984: 31). Keohane explains that when the power of hegemonic state becomes equal to other powerful states, it is more difficult for the hegemonic state

6) See: Stephen D. Krasner, 1983, International Regimes (Ithaca, NY: Cornell University Press), p.2. "sets of implicit or explicit principles, norms, rules, and decision-making procedures around which actors' expectations converge in a given area of international relation" 
to assert principles and institutions of international regimes to other states, and therefore, its influences are bound to become weaker (Keohane and Nye 1987: 42-46).

With the power deterioration of the hegemonic state, the interest relations on international regimes among other states are also likely to change. If the capability of hegemonic state for providing public goods weakens, other states would decrease their support for the international aviation organization, and moreover, they would like to reorganize the international regimes to their own benefits. In an environment as such, international regimes can deteriorate more, and finally to make it impossible to achieve interstate collaboration or stability of international regimes. In the theory of hegemonic stability, the formation, maintenance, and deterioration of international regimes are all decided by the hegemonic power change. As international public goods, international aviation regimes were provided by the hegemonic powers.

\section{(2) Neo-liberalism}

The neo-liberalism theory is based on the logic that international institutions, such as UN and ICAO, can maintain the regularity of human behaviors by arranging international treaties, conventions, and agreements on principles, norms, rules, and decision-making procedures among states (Thelen \& Steinmo 1992: 1-32). It seems that functional necessities of institutions lie in regulating and guiding behavioral norms of individuals or organizations. The neo-liberalistic institutionalism, drawing attention in the US academy since the 1980s, is believed to perform as a means or a coordinator for actors' collaboration in international aviation regimes (Lamy 2001: 182-197) ${ }^{7}$. In the other hand, Andrew Moravcsik argued that liberalism is logically prior to institutionalism or realism (Moravcsik 1997: 516).

However, in most of major interactions among different states, it is neither easy to make policies independently nor maximize the interests through such interactions. This fact leads rational and egoistic actors to make collaborative decision to create aviation organizations like ICAO in order to avoid the worst cases and acquire the most benefits (Axelrod 1981: 306-318). Game theorists say that since international regimes fulfill the conditions required for interstate collaboration, states tend to acquire motives to maintain international regimes on egoistic purposes to increase their benefits through such collaboration. In this case, it is studied that collaboration is required for solving

7) Neo-liberalistic institutionalism is developed emphasizing the necessity of institutions with the $1^{\text {st }}$ generation based on the roots of the neo-liberalism, the $2^{\text {nd }}$ generation based on the regional integration, and the $3^{\text {rd }}$ generation based on trans-nationalism and complex interdependence (Lamy 2001: 188-189) 
dilemmas of common interest, whereas coordination is required for solving dilemmas of common aversion (Krasner 1983: 127-128; Stein 1993: 29-59).

Using English as a common language in air traffic control centers is one example of coordination for solving dilemmas of common aversion. All flight control centers must employ English-speaking workers to direct to all pilots who pass their own skies and who don't speak the languages of their own. The communication between ground control center and pilots in the sky can be any language which they find comfortable with. However, the language must be communicable, and the match-up of languages is something never to be left to a chance. This is the reason why the official common language for flight control centers is English.

For instance, a pilot who flies within Korean airspace needs only speak Korean. It is also acceptable if a pilot of a French airline flying in Korea's FIR (Flight Information Region) tries communication with the control center in Korean. However, if the pilot does not understand Korean, and the controller does not understand French, then the communicating language must be English, because the possibility of aircraft disaster caused by inaccurate communication can be the object of common aversion and safe operation is only secured by avoiding such miscommunication (Krasner 1983: 127-131; Stein 1993: 43-44). This is a good example that shows the principle of cooperation and coordination in which the choice is made at the equilibrium point of the two sides - the pilot and the control center - in order to avoid the dilemma of common aversion.

Neo-liberalism theories, such as rational choice theory, functionalism, and game theory contribute to maintain international aviation regimes.

\section{(3) Social Constructivism}

This stems from epistemic community theory. The social constructivism theory based on cybernetics and cognitive process of psychology to be more focused on the cognitive process. The social constructivism theory based on collective knowledge and cognition, stressing more emphasis on central process as attitudes, thoughts, and expectations over peripheral factors as stimuli and responses, is often used as a term compared to the theory of behaviorists. The obvious characteristics of the social constructivism theory in comparison to the behaviorist theory lie in the emphasis that the factors as shared or collective ideology, belief, and knowledge of decision-makers play significant roles in formation and transformation of international regimes (Wendt 1992: 395-410).

Whereas the realism of hegemonic stability draws international collaboration from hegemonic struggle for political authority, and the functionalism and game theory of neo-liberalism draws cooperation from assumption on motivation of an actor pursuing 
economic benefits, the social constructivism theory of epistemic community explains the aspects of cooperation based on the change and improvement of specific knowledge. It insists that shared knowledge and understanding within a community is extremely important for international collaboration in world politics in state of anarchy.

The social constructivism theory is raised on its main assumption that changing the practices changes the inter-subjective knowledge that constitutes a system (Wendt 1992: 407). That is, whether it is possible to change the practices from worldwide actors is strongly influenced by cognition right or wrong, knowledge old and new, history and ideology, dominant social value, capability of information processing, learning, etc. Only through the consensus in cognitivism among worldwide actors, true cooperation can be achieved (Hasenclever, Mayer, and Rittberger 1997: 136-139).

Hasenclever, Mayer, and Rittberger specify the cognitivism of actors in the international society mainly into weak cognitivism and strong cognitivism. While weak cognitivism focuses on the origins and dynamics of rational actors' understandings of the world - such as ideas, learning, role of epistemic communities, etc, strong cognitivism focuses on the origins and dynamics of social actors' self-understandings in relation to others - mutual relationship in world politics (Hasenclever, Mayer, and Rittberger 1997: 136-139).

Ernst B. Haas sees that actors start learning when they feel deep connection to each other. As the result of such learning, new knowledge is produced for use in re-defining the interests of the state or the actor himself, and in this process, the collaboration is further achieved, and institutionalized in a good way. The institutionalized collaboration can be studied from a perspective of interaction between transforming knowledge and changing social values. In his theory, the specialized technicians with principled ideas and shared understanding play important parts for the formation and transformation of international regimes (Haas 1975: 827-876).

The role model of flight control center is a good example; where pilots and controllers with shared understanding and expertise create an integrated cognitive community on certain boundary of issues across borders. Global issues or problems - such as human rights, environments, weather and climate, pollution, health, and aviation cannot be solved by governments, individuals, or air carriers alone. However, the consensual knowledge of scholars or technicians with expertise performs significant roles on such complex issues that require mutual dependency (Hasenclever, Mayer, and Rittberger 1997: 150; Peter Haas 1992: 23). The shared consensus, knowledge, and epistemology are very important and necessary factors for the collaboration and coordination in high technological and professional fields, such as flight operation, tariffs, schedules, and 
aircraft development of international aviation

The above three theories on the international regimes respectively have strengths and weaknesses, and any one of the theories cannot thoroughly describe the formation, development, and sinking of international regimes. Today's international aviation sector mainly follows the global trend of social constructivism in the world economy, with pursuit of hegemonic stability and building of neo-liberalism as complementary means especially in the aviation issue-area. The following four chapters (II - VI) will explore and investigate four independent variables suggested in the chapter I .

\section{Power Structure}

The power structure of the international society has transformed to the pluralism after experiencing the World Wars and decline of the Soviet Union. Then how has the international aviation order changed? As Keohane and Nye have analyzed, the change of international regimes in the cold war were in the hands of the US and the Soviet Union for hegemonic struggle (Keohane and Nye 1989: 42-49).

According to Joensson's analysis on the change of international aviation regimes, the participating member countries of the Paris Convention 1919, which was held after the World War I for establishing the international aviation order, considered national security the most important over any other issues among international affairs. After the World War $\mathbb{I}$, it was still the same for the member countries in the Chicago Conference. Therefore, Joensson argued that there was no change in the power structure in international aviation regimes after the two World Wars (Joensson 1981: 294-296).

However, with breakthrough of Soviet Union and prevalence of pluralism throughout the world in the 1990s, many actors are interested in various issue-areas besides the military forces or security. Major changes caused by these are as follows;

First and the most obvious is the emergence of NGOs. The current NGOs object to unjust decision-or policy-making by governments or other interest groups on issueareas across borders. Especially in the aviation sector, many issues - environmental contamination, air pollution, noises, unreasonable tariff rates, and services - are raised as for improvement by environment and transport-related organizations. The European Federation for Transport and Environment (T\&E) is one example of these organizations. ${ }^{8)}$

8) European Federation for Transport and Environment (T\&E) is a pure private NGO established in 1989 for monitoring the performance of Transport Commission of the European Union. 
Second are the organizations of regional integration. For decades, the economic and political integration of regions has promoted free competition in producing and exchanging goods and services without barriers. The European Union (EU) has achieved the most systematic advancement in political and economic integration. The air transportation policy of EU, concluded on 7th January, 1993, adopted incredible deregulation compared to the Chicago Convention. Even though the systematic tools are not as clear as those of EU, the movement for the regional integration throughout the world is becoming more obvious and increased.

Third is the emergence of organizations with new roles such as World Trade Organization (WTO) for one example. As discussed above, how the regional integration will change the international aviation organization such as ICAO in the future is keenly watched. And as one of the results, the General Agreement on Tariffs and Trade (GATT) of December 1993, the former WTO, has integrated the fields of international air transport into service trades, causing influences on the change of roles and scope of ICAO.

Fourth is the change in the concept of sovereignty over the airspace, which is also the criterion for classifying and defining characteristics of international aviation regime into old or new. The concept of state sovereignty originates from the Peace Treaty of Westphalia of 1648, which was established for balance of power after the 30-year war in Europe. However, the concept of sovereignty over the airspace had not existed from the 1783 first flight of balloons until the 1919 Paris Convention. Then with the breakout of World War I, there happened many cases flying over the airspace of other states, and the regulations on sovereignty over the airspace came to be established.

Fifth is the concept of post sovereignty over the airspace. Taking into consideration the globalizing trend of today's sovereignty over the airspace, what influences are made by such globalization onto state sovereignty? Does the sovereign states itself contribute to or disturb the improvement of globalization and achievement of ideal societies? There are two theories for this one that weakened state sovereignty (Strange 1996: 56; 1997: 368-369) and the other that strengthened it (Krasner 1999: 34). It is considered quite extreme that such theories on the sovereignty over the airspace are against each other. In reality, actors of official organization including states take important roles in globalization through organizations like WTO, the World Bank, IMF, etc. However, with the emergence of unofficial actors like NGOs, the redefining of their relationships became necessary. It is true that new types of state roles are now asked for.

There are two points that should be considered in classifying international aviation regimes by time scopes and characteristics. One is that such classification does not 
mean alienation from each time scopes. The other is that it is the dialectic process in which one regime is transformed into a more developed one based on the systems in the past (Barrington Moore 1966: 247-248)').

On the other hand, the internal power structure of ICAO roots back to 1944 when 52 states that signed the Chicago Convention had the power to discuss and decide the draft of the convention on behalf of the international society. In the end of 2003, the number of contracting states has increased to 188 states $^{10}$. The 136 states that joined later, which take up $72.34 \%$, could not give any influence on the Chicago Convention, but since they participated in general consensus, they are now equally eligible with the signing states in 1944.

The competitive interests and relationships of the international society, based on the conditions of world's geopolitics and their member states, have largely changed since the Chicago Convention. In 1944, the Soviet Union and other hostile states were firmly excluded, and only the US centered western blocs have participated in signing it. However, in the 1960s and 1970s, many states that have emerged through decolonization joined ICAO and cast their votes, further changing the directions for ICAO to initiate the policies. They emerged asa new power group in international aviation society, constituting more than a half of the entire members of ICAO, and brought various ideas and interests of the international society upfront ${ }^{11)}$.

So far has been the analysis of the power structure of international aviation from two different points of views - external and internal. For the external point of view, new actors - NGOs, WTO, ILO, World Bank, OECD, environmental organizations were formed as a result of world's pluralism and set forth their opinions. For the internal point of view, ICAO has reformed its organizational structure, in which more states have joined in addition to the 52 states who signed the Convention to become a total of 188 and change the power stream. According to A. Moravcsik's core liberal assumptions "The primary of individuals and private groups is prior to politics. Liberal theory is logically prior to realism and institutionalism because it defines the conditions under which they hold." (Moravcsik 1997: 516-519), aviation endogenous variables (ICAO, IATA etc.) are prior to such exogenous variables (WTO, IMF, OECD, World Bank, etc.).

9) Barrington Moore Jr. sees Japanese modern state established not alienated from the former era of Tokugawa Shogun but based on their feudal system and their development of industrial techniques for the Meiji Restoration that started in 1868.

10) ICAO, Journal, Vol.58 (2003).

11) From the 1994 memorial speech for 50th Anniversary of Chicago Convention by Dr. Michael Milde, Institute of Air and Space Law, McGill University, Canada. 


\section{Economic and Technological Importance}

It seems that there are about three reasons to cause actors of international aviation to pursue international regimes such as conventions and agreements: 1) they consider such regimes beneficial to their own states in the long run; 2) international aviation regimes will reduce the uncertainties through communication and learning, and will further enhance transparency; 3) the international aviation regimes contribute to standardization and simplification of various issues by expansion of issue-areas through regular institutionalization. The ultimate goal for such pursuit is to maximize economic gains with the use of information technology, and to decrease transaction cost through the reduction of uncertainties. However, due to the increase in individual incomes and development of scientific technology, the international aviation order is drastically changing in reality.

\section{Economic Growth}

The impacts of economic growth signify the important change of issue-areas on international aviation regimes. The logic is that the broader concept of political issues such as war, military, security, and authority is not preferred anymore. Instead, other issue-areas, such as trade, finance, environment, and human rights, are selected and prioritized in accordance with their preference. It is the same for the issue of international aviation regimes. The development of economy and scientific technology have made the users prefer traveling, and therefore, increasing the amount of transportation. Such qualitative increase and the change in users' preference have also diversified travel destinations.

〈Table 1〉 Regional Share of International Air Transportation (Tonne-kms)

\begin{tabular}{|c|c|c|c|c|c|}
\hline Region & $1973(\%)$ & $1988(\%)$ & $1997(\%)$ & $1999(\%)$ & 2002(\%) \\
\hline Asia Pacific & 14.1 & 29.0 & 32.6 & 30.4 & 33.7 \\
\hline North America & 27.5 & 21.5 & 19.8 & 21.0 & 19.0 \\
\hline Middle East & 4.0 & 4.9 & 4.3 & 4.5 & 5.2 \\
\hline Latin America & 6.3 & 5.7 & 5.0 & 5.0 & 4.0 \\
\hline Europe & 44.3 & 35.5 & 35.8 & 35.5 & 35.5 \\
\hline Africa & 3.8 & 3.4 & 2.5 & 3.6 & 2.6 \\
\hline Total & 100.0 & 100.0 & 100.0 & 100.0 & 100.0 \\
\hline
\end{tabular}

(Source: ICAO, Air Transport Reporting Form A (2002 Statistics) Mr. Attilio Costagura, Chief, Statistics Section, ICAO) 
According to 〈Table 1〉, only $14.1 \%$ of international air transportation in 1973 took place in the Asia-Pacific region. However, in the end of 2002, it has increased up to $33.7 \%$. The top-ten airlines for tonne-kilometers of international air transportation include four Airlines in Asia - Singapore Airlines, Japan Airlines, Korean Air, and Dragon Air in Hong Kong. Paradoxically, it means that airlines in Europe and America have lost as much share as airlines in Asia have gained. In 1973, airlines of America and Europe have transported $71.8 \%$, more than $2 / 3$ of the total, and the share decreased to $54.5 \%$ in 2002. Airlines in America even ranked from the second in 1973 to the third in 2002. In the meanwhile, Airlines in Asia have ranked the second, almost at the equal level of the airlines in Europe that rank number one. What is even more threatening is the speed of population and economic growth in China and India. They hold the potentiality for aviation market growth in the region.

\section{Technological Development}

Together with the technical development, the aircraft productivity is increasing. As 〈Table 2〉 shows, the average productivity of an aircraft in the 1930s to 1950s was below $10 \mathrm{t}-\mathrm{km}$. However, it was enhanced above $10 \mathrm{t}-\mathrm{km}$ in the 1970s, and even more than 30 $\mathrm{t}-\mathrm{km}$ in the late 1990s. With the new aircraft model A380 in commercial use after 2006, the productivity is expected to record above $52 \mathrm{t}-\mathrm{km}^{12)}$ (Doganis 2002: 10).

〈Table 2〉 Technical Development: Productivity Increase of an Aircraft

\begin{tabular}{|c|c|c|c|c|c|c|c|c|c|c|}
\hline Aircraft & 1936 & 1952 & 1956 & 1959 & 1969 & 1974 & 1976 & 1988 & 1995 & 2005 \\
\hline DC-3 & 0.5 & & & & & & & & & \\
\hline Lockheed & & 3.8 & & & & & & & & \\
\hline Britannia & & & 6.2 & & & & & & & \\
\hline Caravelle & & & & 4.7 & & & & & & \\
\hline B747-100 & & & & & 31.5 & & & & & \\
\hline A300 & & & & & 19.8 & & & & \\
\hline Concorde & & & & & & & 19.3 & & & \\
\hline A320 & & & & & & & & 11.9 & & \\
\hline B77-200 & & & & & & & & 33.5 & \\
\hline A380 & & & & & & & & & & 52.5 \\
\hline
\end{tabular}

※ Note : Productivity per hour in 1930s - 1950s: 0.5 6.2 t-km ph

Productivity per hour in 1970s - 1980s: $11.9 \sim 31.5 \mathrm{t}-\mathrm{km}$ ph

Productivity per hour in/after 1990s: $33.5 \sim 52.5 \mathrm{t}-\mathrm{km}$ ph

12) Productivity per hour is calculated with tonnage multiplied by kilometers ( $t-k m$ ph). 
The scientific technology development after the 1990s has changed the direction of international aviation regimes into creating new relationships with customers using the Internet and electronic commerce. The technical development also reduced uncertainties and transaction cost, further expecting new changes in life styles as well as in travel destinations.

The $21^{\text {st }}$ century has accelerated more economic globalization. The world has become integrated into one unified economic and life zone as the technology developed and the number of the Internet users increased.The needs and desires of air service customers have also become diversified in the globalized process. They now ask for more convenient and prompt services. Like this, the globalization of human movement explains the change of international aviation regimes from sovereign states-focused governance ${ }^{13)}$.

As the level of human movement globalization improves, the fundamental governance, the keynote of traditional international aviation regimes, is also asked to change. The needs for change in governance insist that human capital replace the traditional theories, forcing modifications in the existing theories. It is because, in order to produce high-quality services and goods in such special sector as aviation, material and human resources with highly specialized techniques and knowledge are required.

The traditional regime theories of international aviation inevitably needed modifications due to some changes. The criteria of international aviation governance under open sky policy changed the contents of Chicago Convention, which had been signed on the basis of sovereignty over the airspace with general regularity. The concept of a nation-state is modified and the concept of knowledge-based society is introduced into the traditional theories such as human resources training, education, know-how, etc. with the development of information technology and the Internet. Such modifying trend is well shown in the 'open skies' agreement between the US and the Netherlands in 1992. The freedoms over the airspace came to be unlimited before the Chicago Convention. And for liberalizing aviation within EU, the $8^{\text {th }}$ freedom right or cabotage, once long been strictly limited, was completely unrestricted among 25 states including 10 Eastern European states since May 2004. From the traditional aerial sovereign point

13) The magazine 'Foreign Policy' produces globalization index of each country annually since 2001. It is measured by integrating thirteen key index, categorized into four economic index (trade, overseas direct investment, portfolio, income, etc.), human globalization index (tourist movement, individual share of total telephone calls, amount of overseas remittance, etc), technical index (internet users, internet hosts, number of servers, etc), and political index (membership in international organizations, participating projects in world peace activities, number of embassies, etc). 
of view, the fact can mean the end of sovereignty (Camilleri and Falk 1992: 236-257). This can be understood from the logic of reform and change, which emphasizes the concept of new knowledge in establishing aviation order.

\section{Issue Structure}

Keohane and Nye insist that the political issues like the first oil crisis of Middle East in 1973, and not the military security, are the key factors that change international regimes in terms of dynamics of international political economy (Keohane and Nye 1989: 49-54). They also explain that the world's order for international trade and tariffs is maintained by GATT.

Joensson studied the change of order system in the international aviation sector, and stressed the capability to raise states' air transportation demands as the key factor for change in international aviation regimes. To enhance air transportation capability of a state, geopolitical position and ownership of a large territory are required. They are necessary to limit international routes and to use as a gateway for imposing limitations on foreign air carriers. In addition, strategic location for refueling, en route communication, and navigation aids, as well as aeronautical know-how and industry are also considered important (Joensson 1981: 296-299).

However, during the war, the aviation power held diplomatic and military significance in the heart of European world politics due to the limitation of navigation distance of aircraft and competition among Western European countries. Germany became one of the leading states in aviation sector after rising from the ruins of the World War I, and after the World War $\mathbb{I}$, the international aviation society for the US and the Soviet Unions to lead was formed. In the meanwhile, bilateral air services agreements were stipulated such as the Bermuda agreement between the US and Britain. Then, how has the ownership of air carriers changed since the world wars, and what are the main issues in market order?

\section{Ownership of Air Carriers}

Which one among the national security, airlines benefits, and air service users should control the directions and types of international aviation regimes? After the World War II, states took control of managing private air carriers to improve their weak structures, and this can be explained with the theories of market failure and government failure. 


\section{(1) Nationalization as Alternatives of Market Failure}

This theory insists that the goods and services provided in market by businesses should satisfy the basic needs of the society. If the businesses could not satisfy such needs through market mechanism, it is the duty of the government. Most of the air carriers established by retired pilots of the World War II, except for some in the US and other major countries, had weak financial grounds. And most of them were taken over by their governments, or nationalized.

However, these nationalized air carriers came to weaken their competitiveness due to strict regulations and accumulated deficit. Finding it difficult to provide customers with high quality services and to establish reasonable tariff, governments promoted deregulation, liberalization, and privatization of businesses, and the ownership in turn went back to the private.

\section{(2) Privatization as Alternatives of Government Failure}

As mentioned above, it is the goods and services provided in market by businesses that satisfy the basic needs of the society. However, there can be failures caused by the irony that businesses must pursue profits and still must satisfy the social needs. Governments' take-over can be an alternative for the market failure, but such nationalization can also end in failure due to over-investment and extreme budget allocation. The theory of privatization provides alternatives for government failure. The more capacity the privatized businesses have in mobilizing human and organizational resources, the more efficient their activities become. The index for analyzing human and organizational resources in privatized businesses includes the number of membership, revenue, leadership, and expertise.

\section{Market Order}

The globalization of people's movement provides opportunities for fair and equal competition of air carriers. According to statistics of World Tourism Organization(WTO), the number of tourists in 1960 was only 70 million, whereas it jumped up to 500 million in 1995. As of 2002, it reached 715 million worldwide, which shows that the annual total number of tourists is exceeding the total number of world's population, which is approximately 650 million.

Alexis de Tocqueville, a French national of the 19th century, said that he had learned democracy of the US by traveling America (Alexis de Tocqueville 1955). Even at this moment, more than 700 million people every year as of 2002 are scattered throughout 
the globe, and are learning democratic ideology and traditions as well as cultures of each region. The citizens of the world are learning at any part of the world to manage democratized and transparent politics and at the same time to monitor and disseminate through NGOs. The roles of NGOs that contribute to establishing international regimes are: (a) advising, (b) supporting, (c) justifying, (d) coordinating and arbitrating, etc. (Kim Young Ho 2001: 30-33).

The 1830s when Tocqueville traveled the US in order to learn democracy was the time when there were no regular scheduled international flights, and the opportunities for traveling were very limited to the few wealthy elites. However, anybody now has the same opportunity as Tocqueville. The increase in travel opportunities together with the increase in information acquisition leads to the participation for the traditional peripheral groups to take political roles. And therefore, the quality of democracy is expected to be enhanced. The increase in information acquisition is actualizing the dream of a planetary village, as Marshall McLuhan had mentioned, under slogans such as telecommunication satellites, world's information super-highway, and global information society.

The globalization of open information providing all the people in the world with the same and equal opportunities seeks ways to provide fair and equal opportunities for competition in international air transportation. The liberalization and globalization of aviation should be achieved from the viewpoint of free and fair competition. ${ }^{14)}$ In order to achieve it, appropriate safeguards are required to guarantee efficient and sustainable participation of all air carriers.

Looking into the types of people's movements, one side performs as the basic casual factor for creating the other side, whereas the other side performs as outcomes or creates patterned behaviors. Especially the work of drawing the establishment of international aviation regimes or macro behavioral norms through microanalysis of such movements is originated from Max Weber's Protestant Ethic and the Spirit of Capitalism (Weber 1958). Weber argued in regard to the doctrines of the Calvin that unexpected accumulation of capital with individual discipline and industry, which has no casual relations with capitalism, brings a new form of macro behavioral norm - the capitalism. Therefore, he stresses that without the precedent values of the capitalism such as industry, self-sacrifice, loyalty, and dignity, the capitalism will not flourish. The relationship between peoples' movement and international aviation regimes can be

14) The result of the $5^{\text {th }}$ Air Transport Conference (ICAO Headquarters, Montreal, Canada, March 24-28, 2003): The Agreed Minutes announced at the end of the Conference emphasizes the provision of fair competition opportunities. 
also explained from the understanding of the relationship between micro individual behaviors and macro patterned behaviors.

Opportunities for fair competition in open societies can be also offered by associations of customers, such as consumers' groups and the shipping associations, replacing the state and the market, which may fail to achieve the duty.

As explained so far, the motive for increasing economic interests has changed together with the development of scientific technology and economic growth. Thanks to the use of the Internet and development of aircraft, the cost has been reduced and many travel destinations have been developed, creating new forms of relationship with customers and even their lifestyles. In this new era, the sovereignty over the airspace is also characterized by co-ownership and relativity. The sovereign concept over the airspace of aviation order is becoming blurred by its liberalizing movements within Europe. Sovereignty is an element for convenience of human life and is considered as internationally shared, relative concept in harmony with cooperative atmosphere. Such change in the sovereign concept over the airspace characterizes aviation order led by the users.

Based on the customer sovereignty in the international aviation society, people can have the rights to use unreserved seats, to ask for reasonable countermeasures in mileage application and noise issues, etc. In reality, a close cooperation between the airlines and customers is required in order to prevent fake reservations caused by customers not notifying the airlines of their cancellations. As for the issue of fair application of airlines mileage, the states and user's associations should try their best to disclose the facts and results caused by unilateral change in provisions. Citizen organizations and the states also should let out objective facts in regard to aircraft noises, whether there are violations or sufferers in residence. These issues are the categorized as consumers sovereignty, in which the absolute state power is transferred to the relative civil societies.

\section{Relationship with WTO}

The liberalization of air transport services by WTO demands that the service levels meet the international criterion. The general agreement on trade in services (GATS) clarifies in the section 2 to Annex on air transport service that services directly related to the air transport right and its exercise are excluded from the agendas for negotiations, but the three agendas are regulated in the section 3 to the Annex; 1) 
aircraft repair and maintenance, 2) selling and marketing of air transport services, and 3) computer reservation systems, that can be negotiated. Also it is stipulated in section 5 to Annex that the contents are to be examined every five-year to consider if there are any additional applications in GATS. WTO discusses whether the current system will still remain or other aspects will also be included.

The following is the lists that may be added to the air transport services, as discussed in ICAO Worldwide Air Transport Conference in March 24-28, 2003, Montreal, Canada:

a. Safety and security aspects of liberalization

b. Liberalization of air carrier ownership and control

c. Liberalization of market access

d. Aircraft leasing

e. Liberalization of transport of air cargo

f. Safeguards to ensure fair competition

g. Sustainability and participation

h. Consumer interests

i. Product distribution

j. Dispute resolution under liberalized environment

k. Transparency of international aviation regulations

1. Review of template air services agreements: TASA

m. Mechanism to facilitate further liberalization

With respect to the above aspects, UNCTAD advises that the opinions of developing countries must be considered. The International Chamber of Commerce (ICC) especially insists that air cargo sector must be newly added and the ICAO Air Transportation Meeting of 2003 had seen the discussion almost liberalize the sector open up to the $7^{\text {th }}$ freedom $^{15)}$. Unlike the past, the issue structure is also transforming for the benefit of users since the 1990s.

\section{International Organizations}

Keohane and Nye assume that once multi-networks, norms, and regulations are

15) Korean air's opinion on the matter follows the ICAO's opinion that whether to accept provisions of MFN of GATT is left to discretion of each country. (from an interview with the Executive Director of Korean Air and participants at 2003 ICAO Air Transport Meeting). 
established, it is hard to make modifications and it may even block the harmony between important power structure and regime change. A regime is established in line with the distribution of resources and the established networks, norms, and regulations affect the capability of actors to use resources. For example, the Bretton Woods Agreement controls the international finance and monetary rules; 'One state one vote' system of UN balances the powers between the hegemonic and non-hegemonic states; and international institutions and regulations bind member states of international organizations (Keohane and Nye 1989: 54-58).

Christer Joensson considers that the emergence of multinational corporations such as SAS, Concorde, and Airbus in non-American region, or the Europe, led to changes in aviation regimes. He also insists that meetings of ICAO held in a form of forum provides equal opportunities to express ideas for both hegemonic and non-hegemonic states, and the unanimity system in rate-making machinery of International Air Transport Association (IATA) is the exercise of equal rights of the strong and the weak, therefore raising the two aspects as the causes for change in international aviation rules (Joensson 1981: 299-301).

Today's aviation institutions and organizations are fast changing not only in terms of its functional roles but also inbuilding new networks with the $3^{\text {rd }}$ organizations, NGOs, and customers.

\section{The 3rd Organizations}

Aviation organizations are composed of ICAO as an inter-governmental organization (IGO), IATA as airlines' organization, and the $3^{\text {rd }}$ organizations as host of others. With the emergence of the $3^{\text {rd }}$ actors into the aviation sector, it is noted that the government interests in international aviation decreased and the essentials changed (Joensson 1981: 285). 〈Table 3〉 shows the three classifications of aviation organizations into IGOs, NGOs and the $3^{\text {rd }}$ organizations. The US has the White House, DOT, and FAA as its governmental aviation organizations, ATA and NACA as its carrier's organizations, and trade union and aviation consumer action project as a consumer-interest group of the 3rd organization. 
〈Table 3〉 Classification of International Aviation Organizations

\begin{tabular}{|c|c|c|}
\hline $\begin{array}{c}\text { Inter-governmental } \\
\text { Organizations }\end{array}$ & $\begin{array}{c}\text { Air carriers' } \\
\text { Organizations }\end{array}$ & $\begin{array}{c}\text { THE 3RD other } \\
\text { Organizations }\end{array}$ \\
\hline EUTC & AEA & AACC \\
EUROCONTROL & AAPA (OAA) & UFTAA \\
TCAA & AACO & WTO(*tourism) \\
LACAC & AFRAA & IFALPA \\
ACAC & IACA & FIATA \\
AFCAC & & \\
\hline
\end{tabular}

Source : Christer Joensson, op.cit., 1981, pp.284-285; Hong Soon Kil, 'New Aviation Law' (Korean), 1999, pp.87-90

\section{Aviation NGOs}

Some modifications have been made to the membership qualifications of International Air Transport Association (IATA). The mandatory regulation of joining rate machinery was removed. With this change, new independent air carriers of the $3^{\text {rd }}$ world entered into the bloc, expanding the power of IATA as strong as that of ICAO.

〈Table 4〉 Functional Changes of IATA

\begin{tabular}{|c|c|c|c|}
\hline Types & 1944-1978 & 1978-1992 & 1992-2005 \\
\hline Member airlines & $\begin{array}{c}\text { 61 airlines of 32 } \\
\text { countries (1945) }\end{array}$ & $\begin{array}{c}90 \text { airlines (1970s) } \\
130 \text { airlines (1980s) }\end{array}$ & 246 airlines (2001) \\
\hline $\begin{array}{c}\text { Entrance condition of } \\
\text { rate-machinery }\end{array}$ & Mandatory & $\begin{array}{c}\text { Separation of entrance } \\
\text { (Trade and tariff) }\end{array}$ & Free entrance \\
\hline
\end{tabular}

In the stage of pluralization, governmental organizations are not capable enough to provide solutions for international aviation issues. Many outer factors caused by globalization of regional characteristics, WTO's air service liberalization, and uncertainties on aviation security are bringing various new actors besides the state and air carriers, strengthening their rights and interests. Aviation consumers' organizations, aviation labor organization, and European Federation for Transport and Environment (T\&E) are the examples of such organizations. It is expected that these pure aviation NGOs are to increase.

The aims of the establishment of $\mathrm{T} \& \mathrm{E}$ are to achieve sustainable transport improvements for realization of environmentally responsible, economically sound, and socially just transport environmental sector and to have many political decisions on environmental destruction caused by transport made in their region. They are involved in general fields of transport and environment, including decision of reasonable tariff, 
limitation on vehicle exhaust, standardization of fuel quality, tax, basic facilities fund, maintenance of safety, standardization of air pollution, deregulation, etc. Also, they publish regular newsletters and monthly papers, as well as briefing materials for press conferences for collaboration and information exchange.

The members of T\&E are 40 NGOs from European Free Trade Association (EFTA) and 20 countries including Middle Eastern Europe, and it holds annual assembly, the top decision-making structure, and regular meetings every three months. It maintains horizontal relationships with its members and collaborative connections with other NGOs and even CEOs, employers, and experts in railway, auto vehicle industry, road traction, shipping, etc. In terms of transport system, it involves in all parts of transportation including land, rail, air, sea, and non-motored transport. After the 9.11 terrorist attack in 2001, T\&E was granted the position of an observer by ICAO for the first time, and performed as a coordinator for unification of world' s aviation NGOs. In a recent newsletter of June 2003, it disclosed the intention of UN Transport Committee to relinquish to decide reasonable tariff, and insisted that it would continuously drive efforts to correct it.

In terms of UN, the Article 71 of Chapter 10 of UN Charter is referred to for the origination of NGOs. It describes: "The economic and social council may make suitable arrangements for consultation with nongovernmental organizations which are concerned with matters within its competence. Such arrangements maybe made with international organizations, and where appropriate, with national organizations after consultation with member of the United Nations concerned." Based on the use of the term 'consultation' in the Charter, IATA is engaged in rate decision and technical consultations. In addition, new organizations like European Federation for Transport and Environment (T\&E) are established recently and carry out their activities. The restyling of relationships with other international organizations is required as well, mainly with WTO, OECD, World Bank, IMF, etc.

\section{Networks with Customer Relationship}

The international organizations networks are transforming into new relationships with customers. The characteristics of actors who have led the contemporary ideologies are focused on the social constructivism theory, which promotes interdependence with shared knowledge and networking. As an alternative for state-centered approach of powers and interests, it is a theory that emphasizes knowledge dynamics of connection and unification with various actors, communication, and identification. 
These people believe that the networks for defining relationship with customers are as important as the sales networks. The networks for defining relationships mean the construction of an open system that anybody can easily access to, or the installation of

global distribution system (GDS) with sales of related services such as flight and hotel reservations, vehicle rent, tour, shopping, etc. It raises the necessity of establishing global aviation networks, not only domestic networks, for such establishment of GDS can achieve one-stop service system.

These networks can develop functions that naturally bring out systems for customer relationship management (CRM). More naturally connected rather than artificially, it should not only provide customer information for their own use, but also must provide information and convenience for the customers. As the natural rights are given to humans from birth, the relationship between air carriers and customers should be natural. A system is strongly needed in which intermediate systems are not forced to perform market-focused activities, and in which customer rights are guaranteed. Groups with capability to mobilize specialized human resources can only achieve such epistemic communities.

\section{Models and Restyles}

This chapter suggests modeling and restyling of international aviation regimes through connecting independent variables of international aviation regime change with international political change of time periods. The international aviation regimes studied so far can be categorized or summarized into one of the following models and styles.

\section{Models}

The considerations of changes and trends so far studied can be incorporated into 〈table 5〉 as below, which describes; 1) state-centered model based on the realistic theory of hegemonic stability of 1919-1978, 2) airline-centered model based on the neoliberalism of 1978-1992, 3) customer-centered model based on the social constructivism since 1992. 
〈Table 5〉 Periodic Models by Elements of International Aviation Regime Change

\begin{tabular}{|c|c|c|c|c|c|}
\hline $\begin{array}{l}\text { Analytical } \\
\text { elements }\end{array}$ & \multicolumn{2}{|c|}{ Sub-elements } & $\begin{array}{l}\text { State-centered } \\
\quad(1919-1978)\end{array}$ & $\begin{array}{l}\text { Airline-centered } \\
\quad(1978-1992)\end{array}$ & $\begin{array}{l}\text { Customer- } \\
\text { centered } \\
(1992-2005)\end{array}$ \\
\hline \multirow[b]{2}{*}{$\begin{array}{l}\text { Power } \\
\text { structure }\end{array}$} & \multicolumn{2}{|c|}{ Externality } & Military security & Economy & $\begin{array}{l}\text { Emergence of } \\
\text { various actors }\end{array}$ \\
\hline & \multicolumn{2}{|c|}{ internality } & $\begin{array}{c}52 \text { member states of } \\
\text { ICAO }\end{array}$ & $\begin{array}{c}\text { The 3rd world } \\
\text { joining international } \\
\text { organizations }\end{array}$ & $\begin{array}{l}188 \text { member states } \\
\text { strengthening power } \\
\text { of developing } \\
\text { countries }\end{array}$ \\
\hline \multirow{4}{*}{$\begin{array}{l}\text { Economic \& } \\
\text { Technological } \\
\text { Importance }\end{array}$} & \multirow{2}{*}{$\begin{array}{c}\text { National } \\
\text { income }\end{array}$} & $\begin{array}{c}\text { Transport } \\
\text { performance }\end{array}$ & $\begin{array}{c}\text { Europe }>\text { America } \\
>\text { Asia }\end{array}$ & $\begin{array}{c}\text { Europe }>\text { Asia }> \\
\text { America }\end{array}$ & $\begin{array}{c}\text { Europe=Asia }> \\
\text { America }\end{array}$ \\
\hline & & Travelers & NA & 456.8 million & 714.5 million \\
\hline & \multirow{2}{*}{$\begin{array}{c}\text { Technical } \\
\text { develop- } \\
\text { ment }\end{array}$} & $\begin{array}{c}\text { Aircraft } \\
\text { productivity }\end{array}$ & $\begin{array}{c}0.5-6.2 \\
(\mathrm{t}-\mathrm{km} \mathrm{ph})\end{array}$ & $\begin{array}{l}11.9-31.5 \\
(\mathrm{t}-\mathrm{km} \mathrm{ph})\end{array}$ & $\begin{array}{l}33.5-52.5 \\
(\mathrm{t}-\mathrm{km} \mathrm{ph})\end{array}$ \\
\hline & & $\begin{array}{c}\text { computeriza } \\
\text {-tion }\end{array}$ & Almost none & Use in CRS & Use of Internet \\
\hline \multirow{3}{*}{ Issue structure } & \multicolumn{2}{|c|}{ Political economy } & $\begin{array}{l}\text { Politics, military, } \\
\text { security }\end{array}$ & $\begin{array}{c}\text { Economy, trade, } \\
\text { finance }\end{array}$ & $\begin{array}{c}\text { Resources, peace, } \\
\text { environment }\end{array}$ \\
\hline & \multicolumn{2}{|c|}{ Market order } & Market failure & Government failure & Resource failure \\
\hline & \multicolumn{2}{|c|}{ Airline ownership } & State-owned & Airlines-owned & $\begin{array}{l}\text { Professional } \\
\text { management }\end{array}$ \\
\hline \multirow{3}{*}{$\begin{array}{l}\text { International } \\
\text { Organization }\end{array}$} & & $\mathrm{ICAO}$ & forum & forum & forum \\
\hline & & IATA & $\begin{array}{c}\text { Mandatory entrance } \\
\text { for tariff }\end{array}$ & $\begin{array}{c}\text { Free entrance for } \\
\text { tariff }\end{array}$ & $\begin{array}{l}\text { Function of } \\
\text { Financing }\end{array}$ \\
\hline & & NGOs & $\begin{array}{c}\text { IATA, IGO, regional } \\
\text { organizations }\end{array}$ & $\begin{array}{c}\text { IATA, regional } \\
\text { airlines associations }\end{array}$ & $\begin{array}{c}\text { T\&E, the 3rd } \\
\text { interest groups }\end{array}$ \\
\hline
\end{tabular}

\section{(1) state-centered model}

The state-centered model controls aircraft of other state flying in their airspace and stands their sovereignty on the very top in terms of external independency and internal absoluteness. In this period of time, it was difficult to find airlines pursuing profit or providing services for civil users.

The bilateral agreement on air service transportation only allowed operation of agreed routes with the $3^{\text {rd }}$ and the $4^{\text {th }}$ freedom and strongly restricted charter flights. The system of carrier designation was stated in air service agreements, which demanded one-state-one-airline as a rule. Seats and cargo spaces were to be provided equally by both contracting sides and the tariff was to be approved by the two governments. The restrictions were as hard as shells and billiard balls, making it impossible for outsiders 
to penetrate (Doganis 2002: 59).

Since this model is pre-modern style, it seems that it is not fitted for the new developing stage.

\section{(2) airline-centered model}

By accelerating competitions, privatization, and liberalization of air carriers, the airline-centered model brought them out of the first paradigm, when the state controlled and regulated, and provided discretionary power to airlines. The carriers actively promote alliances among airlines with the aim of their sales profit; however, it has not yet reached the level of customer-centered strategic stage.

Air service agreements among states now tend to deregulate restrictions of the $5^{\text {th }}$ freedom and operation of charter flights. For the rule of designation of one air carrier for each, most countries including the US have made it possible to designate multiple carriers. Korea started its multiple carriers system on Korea-Japan routes when Asiana Airlines was established in 1988. There were no limitations on the frequency of operations and types of aircraft, and tariff was considered applicable upon the approval of the aeronautical authorities. Moreover, code-sharing operations between air carriers are prevalent under cooperation without any stipulations in actual agreements (Doganis 2002: 58, 65).

Competitions among the airlines will be continued, but those must be competitive for the civil users.

\section{(3) customer-centered model}

The customer-centered modelis characterized by its focus on enhancing services for the general public. This trend is likely to be continued unless there is a special factor for another change in international regimes. This regime will still continue with collaborative and also conflicting relationship based on trust and cooperation between the state or airlines and the civil users or the $3^{\text {rd }}$ civil society sector with the customers.

Now, bilateral air service agreements do not restrict market access and charter flights operations, and they deregulate the 5th freedom. Even though the 7th freedom and cabotage are still bounded, however it is likely to be allowed soon, considering many cases in European air carriers. Multiple air carrier designation is now common, no limitations on operation frequency, and it is free and open to decide aircraft, tariff, and code-sharing (Doganis 2002: 59).

This model seems to be hopeful to the general civil customers because its purpose is to provide the convenience for their users. 
〈Table 6〉 Periodic Change in Bilateral Agreements

\begin{tabular}{|c|c|c|c|}
\hline Type & $\begin{array}{c}\text { Stage } 1 \\
(1919-1978)\end{array}$ & $\begin{array}{c}\text { Stage } 2 \\
(1978-1992)\end{array}$ & $\begin{array}{c}\text { Stage } 3 \\
(1992-2005)\end{array}$ \\
\hline \multirow{3}{*}{ Market Access } & Specific routes & Agreed routes & No restrictions \\
\hline & $\begin{array}{l}\text { Restriction of } 5^{\text {th }} \\
\text { freedom }\end{array}$ & $\begin{array}{l}\text { Expansion of } 5^{\text {th }} \\
\text { freedom }\end{array}$ & $\begin{array}{l}\text { No restrictions on } 5^{\text {th }} \\
\text { freedom }\end{array}$ \\
\hline & $\begin{array}{c}\text { Restrictions on charter } \\
\text { flights }\end{array}$ & $\begin{array}{l}\text { No restrictions on } \\
\text { charter flights }\end{array}$ & $\begin{array}{l}\text { Open charter flights, } \\
\text { partially open cabotage } \\
\text { sectors }\end{array}$ \\
\hline Carrier Designation & Single & Multiple & Multiple \\
\hline Ownership & State-control & $\begin{array}{c}\text { Designated national } \\
\text { carrier }\end{array}$ & Privatized ownership \\
\hline Capacity & $50: 50$ & $\begin{array}{c}\text { No restrictions on } \\
\text { frequency and capacity }\end{array}$ & $\begin{array}{l}\text { Unlimited frequency } \\
\text { and capacity }\end{array}$ \\
\hline Tariffs & Double-approval & Double-disapproval & Free pricing by airlines \\
\hline Code-share & None & $\begin{array}{l}\text { Not for bilateral } \\
\text { agreement }\end{array}$ & Discretion approved \\
\hline
\end{tabular}

\section{Restyles}

The international aviation regimes examined so far can be restyled as 〈Table 7〉 according to their aims and identities for action. By their aims, state-centered regimes include Paris Conventionof 1919, Chicago Convention of 1944, Bermuda Agreements of 1946 and 1976, and commercial arrangements on specific routes, which play functional roles as supplementary agreements. Airline-centered regimes include US domestic deregulation act of 1978, US international transportation competition promotion act of 1980, and broad based marketing alliance between airlines. Customer-centered regimes include 'open skies' agreement of 1992, airline alliances and frequent flier system in the 1990's.

$\langle$ Table 7〉 Restyling of International Aviation Regimes by Actors and Aims

\begin{tabular}{|c|c|c|c|}
\hline Actors Aims & State-centered & Airline-centered & Customer-centered \\
\hline States & $\begin{array}{l}\text { Paris Convention (1919) } \\
\text { Chicago Convention } \\
\text { (1944) } \\
\text { Bermuda Agreement } \\
(1946,1976)\end{array}$ & $\begin{array}{l}\text { Domestic Deregulation } \\
\text { Act (1978) } \\
\text { International } \\
\text { Transportation } \\
\text { Competition Act (1980) }\end{array}$ & $\begin{array}{l}\text { 'Open Skies' } \\
\text { Agreement } \\
\text { (1992) }\end{array}$ \\
\hline Airlines & $\begin{array}{l}\text { Commercial } \\
\text { Arrangements } \\
\text { on Specific Routes }\end{array}$ & $\begin{array}{l}\text { Broad Based Marketing } \\
\text { Alliance }\end{array}$ & $\begin{array}{l}\text { Airline alliances, } \\
\text { Frequent Flier } \\
\text { System }\end{array}$ \\
\hline
\end{tabular}


Restyling the regimes by identities for their action on conventions, acts, agreements and such, can be classified into 1) multilateral agreements and bilateral agreements - Paris Convention, Chicago Convention, Bermuda Agreement for the state regimes, and 2) commercial agreements - commercial arrangements on specific routes, broad based marketing alliance, and worldwide alliances - for the airline regimes.

The goal of 'open skies' agreement between US and the Netherlands of 1992 is to provide convenience to service users. The main principles, norms, regulations, and procedures of international aviation regimes must restyle their directions in the future for the customers or service users regimes. The future international aviation regime models must be redesigned (or restructured) from this viewpoint, which is also the right attitude for preparing a new coming era of diversity and openness.

Since the 1990s, the direction that led the international regimes shows the tendency to stand more on the customer's side. The aims of service provision in terms of WTO's air service liberalization are also reorganized at the convenience of service users. The realtime service enabled by electronic commerce systems is also a part of restyling the relationships with customers, in which the priorities lie in consideration for victims of aviation industry development and in providing convenience for the service users. Labor movements and disputes in the aviation industry are also following democracy these days. In other words, the air transport order is being restyled not by state authorities or powers but by customers' participations.

\section{Conclusion}

In conclusion, historical summary of the directions of international aviation regimes development offers the following models focusing on the independent variables of international aviation regime change;

First, the major aim was to protect their own aerial domains from other states based on state regulations after the World War II. Second, the state-centered regulations were found difficult to promote market liberalization and competitions, therefore leading to the constitution of deregulation and competition promotion among air carriers. And third, with the emergence of organizations such as WTO, IGOs and NGOs, the demand increased for liberalizing air services and customer rights.

Now is the time for building an international aviation regime for customers. The trend is already following the goal. Through partnerships and alliances among airlines, they offer customers service convenience and through electronic commerce, they also provide 
customers with information on seat availability even right before takeoff. There are good examples of the customer-centric services. Accordingly, we can say that our assumption in the first chapter will orient to the customer-centered services model.

Based on the above modeling and restyling, this study proposes theoretical frameworks for developmental research of international aviation regimes, as well as offers the analytical frameworks for policy-makers of international aviation. In the future, international aviation orders are expected to develop a model focusing on service users and civil societies. Considering the relationships between time period and models of customers, states, and air carriers, a more concrete and restyled model of civilian users is necessary with thorough reflection of the opportunity-divide between the rich and the poor and possible counter-development. 


\section{REFERENCES}

Axelrod, Robert. 1981. "The Emergence of Cooperation among Egoists." American Political Science Review. Vol.75. pp.306-318.

Baylis, John. and Steve Smith. 2001. The Globalization of World Politics: An Introduction to International Relations. Second Edition. Great Clarendon Street, Oxford: Oxford University Press.

Camilleri, Joseph A. and Jim Falk. 1992. The End of Sovereignty?: The Politics of a Shrinking and Fragmenting World. Brookfield. Vt.: Elgar.

Costaguta, Attilio. 2003. Statistics Section ICAO, e-mail address: STA@icao.int, http://www.icao.int

Doganis, Rigas. 2002. Flying Off Course: The Economics of International Airlines. Third Edition. London, UK: Routledge.

---------, 2001. The Airline Business in the 21st Century. London, UK: Routledge.

Donnelly, Jack. 1986. "International Human Rights: A Regime Analysis.” International Organization. Vol.40(3). pp.599-642.

Downs, Anthony, 1957, An Economic Theory of Democracy, New York: Harper \& Row.

Gilpin, Robert. 2001. Global Political Economy: Understanding the International Economic Order. Princeton, NJ: Princeton University Press.

Grieco, Joseph M. 1993. "Understanding the Problem of International Cooperation: The Limits of Neo-liberal Institutionalism and the Future of Realist Theory." in Neorealism and Neoliberalism: The Contemporary Debate edited by David A. Baldwin. New York, NY: Columbia University Press. pp.301-338.

Haas, Ernst B. 1975. "Is There a Hole in the Whole? Knowledge, Technology, Interdependence and the Construction of International Regimes: A Regime Analysis.” International Organization. Vol.29(3). pp.827-876.

Haas, Peter M. 1992. "Introduction: Epistemic Communities and International Policy Coordination.” International Organization. Vol.46(1). pp.1-35.

Haggard, Stephan. and Beth A. Simmons. 1987. "Theories of International Regimes." International Organization. Vol.41(3). pp.491-517.

Hasenclever, Andreas. Mayer, Peter. \& Rittberger, Volker. 1997. Theories of International Regimes. Cambridge, NY: Cambridge University Press.

Hong, Soon Kil, 1999, New Aviation Law (Korean), Seoul: Dongmyoung-sa. ICAO. 2003. Journal, Vol.58. 
Joensson, Christer. 1981. "Sphere of Flying: the Politics of International Aviation." International Organization. Vol.35(2). pp.273-302.

---------, 1987. International Aviation and the Politics of Regime Change. New York, NY: St. Martin's Press Inc.

Keohane, Robert O. 1984. After Hegemony: Cooperation and Discord in the World Political Economy. Princeton, NJ: Princeton University Press.

Keohane, Robert O. and Joseph S. Nye. 1987. "Power and Interdependence Revisited." International Organization. Vol.41(4). pp.725-753.

,-------- 1989 . Power and Interdependence. Second Edition. Cambridge, NY: Harper Collins Publishers.

,--------- 2001 . Power and Interdependence. Third Edition. New York, NY:Addison, Wesley, Longman Publishers.

Kim, Young-Ho, 2001, When do NGOs make Differences in World Politics: An Analysis of the US NGO Policy Advocacy for International Environmental Treaties, Dissertation of the Degree of Ph.D, The Ohio State University

Kofi Annan, 1999, "Responsible Globality Managing the Impact of Globalization," The 29th World Economic Forum in Davos, Switzerland (http://www.weforum.org/publications/press_releases)

Krasner, Stephen D. 1983. International Regimes. Ithaca, NY: Cornell University Press.

--------, 1999. "Globalization and Sovereignty." States and Sovereignty in the Global Economy edited by David A. Smith. Dorothy J. Solinger. and Steven C. Topik. London: Routhledge.

Lamy, Steven L. 2001. "Contemporary Mainstream Approaches: Neo-realism and Neo-liberalism." The Globalization of World Politics edited by John Baylis and Steve Smith. 2nd Edition. Oxford University Press. pp.182-199.

Moravcsik, Andrew, 1997, "Taking Preferences Seriously: A Liberal Theory of International Relatiobns," International Organization Vol.51(4) (Autumn 1997), pp.513-553.

Mearsheimer, John J. 2001. The Tragedy of Great Power Politics. New York, NY: Norton \& Company.

Moore Jr., Barrington. 1966. Social Origins of Dictatorship and Democracy: Lord and Peasant in the Making of the Modern World. Boston: Beacon Press. pp.247-248.

Porter, Michael. 1990. The Comparative Advantage of Nations. New York, NY: Free Press. 
Puchala, Donald. and Raymond Hopkins. 1983. "International Regimes: Lessons from Inductive Analysis." International Regimes by Stephen D. Krasner. Ithaca, NY: Cornell University Press. pp.61-91.

Ruggie, John Gerard. 1975. "International Responses to Technology: Concepts and Trends," International Organization. Vol.29(3), pp.557-584.

Snyder, Glenn H. 1984. "The Security Dilemma in Alliance Politics.” World Politics. 36 (4). pp.461-495.

Stein, Arthur A. 1993. "Coordination and Collaboration: Regimes in an Anarchic World." Neorealism and Neoliberalism: The Contemporary Debate edited by David A. Baldwin. New York, NY: Columbia University Press. pp.29-59.

Stoker, Gerry. 1995. "Regime Theory and Urban Politics." Theories of Urban Politics edited by David Judge. Gerry Stoker and Harold Wolman. London: SAGE Publication Ltd.

Strange, Susan. 1972. “The Dollar Crisis 1971." International Affairs. 48(2). pp.191-216. --------, 1996. The Retreat of the State: The Diffusion of Power in the World Economy. Cambridge, NY: Cambridge University Press.

--------, 1997. "The Erosion of the State." Current History. pp.368-9.

Taneja Nawal K. 1989. Introduction to Civil Aviation, Second Edition, Lexington, Toronto: Lexington Books.

Thelen, Kathleen and Steinmo, Sven. 1992. "Historical Institutionalism in Comparatives." Structuring Politics: Historical Institutionalism in Comparative Analysis. New York, NY: Cambridge University Press.

Tocqueville, Alexis de. 1955. Democracy in America. New York, NY: Vantage Books.

Weber, Max. 1904. Die Protestantische Ethik und der Geist des Kapitalismus (The Protestant Ethnic and the Spirit of Capitalism. New York, NY: Charles Scriber's Sons. 1958)

Wendt, Alexander. 1992. "Anarchy is What States Make of It: the Social Constructivism of Power Politics." International Organization. 46(2). pp.391-425.

Zylicz, Marek. 1991. International Air Transport Law. The Netherlands: Martinus Nijhoff Publishers. 